\title{
Interleukin-10 Receptor Subunit Beta
}

National Cancer Institute

\section{Source}

National Cancer Institute. Interleukin-10 Receptor Subunit Beta. NCI Thesaurus. Code C26270.

Interleukin-10 receptor subunit beta (325 aa, $\sim 37 \mathrm{kDa}$ ) is encoded by the human IL10RB gene. This protein plays a role in cytokine signaling. 